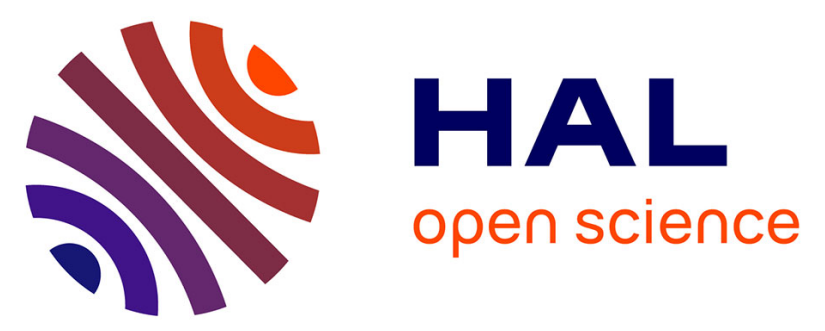

\title{
Comparative analysis of protein expression of three stem cell populations: models of cytokine delivery system in vivo.
}

Stephane Roche, Gianluca d'Ippolito, Adriana L. Gomez, Thomas

Bouckenooghe, Sylvain Lehmann, Claudia N. Montero-Menei, Paul C. Schiller

\section{To cite this version:}

Stephane Roche, Gianluca d'Ippolito, Adriana L. Gomez, Thomas Bouckenooghe, Sylvain Lehmann, et al.. Comparative analysis of protein expression of three stem cell populations: models of cytokine delivery system in vivo.. International Journal of Pharmaceutics, 2013, 440 (1), pp.72-82. 10.1016/j.ijpharm.2011.12.041 . inserm-00802595v2

\section{HAL Id: inserm-00802595 https://www.hal.inserm.fr/inserm-00802595v2}

Submitted on 13 Dec 2017

HAL is a multi-disciplinary open access archive for the deposit and dissemination of scientific research documents, whether they are published or not. The documents may come from teaching and research institutions in France or abroad, or from public or private research centers.
L'archive ouverte pluridisciplinaire HAL, est destinée au dépôt et à la diffusion de documents scientifiques de niveau recherche, publiés ou non, émanant des établissements d'enseignement et de recherche français ou étrangers, des laboratoires publics ou privés. 


\title{
Comparative analysis of protein expression of three stem cell populations: models of cytokine delivery system in vivo.
}

\author{
Stephane Roche, Gianluca D'Ippolito, Adriana Gomez, Thomas
}

Bouckenooghe, Sylvain Lehmann, Claudia Montero-Menei, Paul Schiller,

Stéphane Roche, Gianluca D 'Ippolito, L Adriana Gomez, et al.

\section{To cite this version:}

Stephane Roche, Gianluca D'Ippolito, Adriana Gomez, Thomas Bouckenooghe, Sylvain Lehmann, et al.. Comparative analysis of protein expression of three stem cell populations: models of cytokine delivery system in vivo.. International Journal of Pharmaceutics, Elsevier, 2013, 440 (1), pp.72-82. $<10.1016 /$ j.ijpharm.2011.12.041>. <inserm-00802595v2>

\section{HAL Id: inserm-00802595 http://www.hal.inserm.fr/inserm-00802595v2}

Submitted on 13 Dec 2017

HAL is a multi-disciplinary open access archive for the deposit and dissemination of scientific research documents, whether they are published or not. The documents may come from teaching and research institutions in France or abroad, or from public or private research centers.
L'archive ouverte pluridisciplinaire HAL, est destinée au dépôt et à la diffusion de documents scientifiques de niveau recherche, publiés ou non, émanant des établissements d'enseignement et de recherche français ou étrangers, des laboratoires publics ou privés. 


\title{
Comparative analysis of protein expression of three stem cell populations: Models of cytokine delivery system in vivo
}

\author{
Stephane Roche ${ }^{\mathrm{a}}$, Gianluca D’Ippolito b,c, L. Adriana Gomez ${ }^{\mathrm{c}}$, Thomas Bouckenooghe ${ }^{\mathrm{d}, \mathrm{e}}$, \\ Sylvain Lehmann ${ }^{\mathrm{f}}$, Claudia N. Montero-Menei ${ }^{\mathrm{d}, \mathrm{e}}$, Paul C. Schiller ${ }^{\mathrm{b}, \mathrm{c}, \mathrm{g}, *}$ \\ a Inserm UMR_S 910, Faculte de Medecine de la Timone, Marseille, France \\ ${ }^{\mathrm{b}}$ Department of Orthopaedics, Tissue Bank, Geriatrics, and Interdisciplinary Stem Cell Institutes, University of Miami Miller School of Medicine, Miami, FL, USA \\ c Geriatric Research, Education and Clinical Center and Research Services, Bruce W. Carter Veterans Affairs Medical Center, Miami, FL, USA \\ d LUNAM Université, Ingénierie de la Vectorisation Particulaire, F-49933 Angers, France \\ e INSERM, U646, Unit 646, F-49933 Angers, France \\ ${ }^{\mathrm{f}}$ Institut de Recherches en Biothérapie, Biochimie - Protéomique Clinique, CHU de Montpellier, Université Montpellier 1, 34000 Montpellier, France \\ ${ }^{g}$ Department of Biochemistry \& Molecular Biology, Geriatrics and Vascular Biology Institutes, University of Miami Miller School of Medicine, Miami, FL, USA
}

\section{A R T I C L E I N F O}

\section{Article history:}

Received 14 October 2011

Received in revised form

14 December 2011

Accepted 22 December 2011

Available online $\mathrm{xxx}$

\section{Keywords:}

Cytokine

Delivery systems

Stem cells

\begin{abstract}
A B S T R A C T
Several mechanisms mediate the regenerative and reparative capacity of stem cells, including cytokine secretion; therefore these cells can act as delivery systems of therapeutic molecules. Here we begin to address the molecular and cellular basis of their regenerative potential by characterizing the proteomic profile of human embryonic stem cells (hESCs), mesenchymal stem cells (hMSCs) and marrow isolated adult multilineage inducible (MIAMI) cells, followed by analysis of the secretory profile of the latter stem cell population. Proteomic analysis establishes the closer relationship between hMSCs and MIAMI cells, while hESCs are more divergent. However, MIAMI cells appear to have more proteins in common with hESCs than hMSCs. Proteins characteristic of hMSCs include transgelin-2, phosphatidylethanolaminebinding protein 1 (PEBP1), Heat-Shock $20 \mathrm{kDa}$ protein (HSP20/HSP 6 ), and programmed cell death 6 -interacting protein (PDC6I) among others. MIAMI cells are characterized by the high level expression of ubiquitin carboxyl-terminal hydrolase isoenzyme L1 (UCHL1), 14-3-3 zeta, HSP27 (HSP $\beta 1$ ), and tropomyosin 4 and 3. For hESC, elongation factor Tu (EFTu), isocitrate dehydrogenase (IDH1) and the peroxiredoxins 1, 2, and 6 (PRDX1, PRDX2, and PRDX6) were the most characteristic. Secretome analysis indicates that MIAMI cells secrete higher levels of vascular endothelial growth factor (VEGF), Fractalkine, Interleukin-6, interlukin-8, and growth related oncogene (GRO), compared to hMSCs. These soluble mediators are known to play key roles in angiogenesis, arteriogenesis, atheroprotection, immunomodulation, neuroprotection, axonal growth, progenitor cell migration, and prevention of apoptosis. All these roles are consistent with a reparative pro-survival secretory phenotype. We further discuss the potential of these cells as therapeutic vehicles.
\end{abstract}

\section{Introduction and overview}

Stem cell therapy will probably become a major therapeutic strategy to repair damaged/diseased tissues in the coming years. These self-renewing cells can be expanded in culture providing a continuous source of cells and may further differentiate into different cell phenotypes allowing their use for various clinical applications. Different types of stem cells are being explored for

\footnotetext{
* Corresponding author at: University of Miami School of Medicine, Geriatric Research, Education and Clinical Center and Research Services, Bruce W. Carter Veterans Affairs Medical Center 11GRC, 1201 NW 16th Street, Miami, FL 33125-1693, USA. Tel.: +1 305575 3388; fax: +1 3055753365 .

E-mail address: p.schiller@miami.edu (P.C. Schiller).
}

cell therapy approaches. Among them embryonic stem cells (ESCs), which are isolated from the inner cell mass of the blastocyte and may give rise to tissue specific cells deriving from the three germinal layers, represent a most promising source of cells for cell therapy. Adult stem cells isolated from different tissues throughout the body also constitute an attractive source of cells, as they allow autologous cell transplantation and overcome the immunological, ethical as well as availability concerns encountered with embryonic or fetal cells. Moreover, they are easily expanded, present a large differentiation potential and are hypo-immunogenic, while promoting functional recovery.

The transplanted stem cell-mediated mechanisms of tissue repair may occur by cell replacement or by an indirect paracrine manner. This means that the cells can directly differentiate into the desired cell phenotype and replace the lost cells forming a new 
functional tissue. They can also secrete several growth factors and cytokines involved in immunomodulatory/anti-inflammatory and neoangiogenic processes, cell survival, differentiation and recruitment. Most researchers now agree that ESCs will principally repair damaged tissues by cell replacement while mesenchymal stem cells (MSCs) essentially function as a deliverable factory of targeted mediators of tissue repair with the capacity for replacement of certain cell types in some tissues (i.e. musculoskeletal) (Delcroix et al., 2010; Guillaume and Zhang, 2008).

Human MSCs (hMSCs) isolated from bone marrow represent a heterogeneous population of mixed cells (Ho et al., 2008; Phinney et al., 1999) including stem, and progenitor cells characterized by the expression of CD105, CD73 and CD90, and lack expression of CD45, CD34, CD14 or CD11b, CD79 $\alpha$ or CD19 and HLA-DR surface molecules (Dominici et al., 2006; Ho et al., 2008). The feasibility and safety of bone marrow derived cells have been extensively tested and demonstrated in numerous preclinical studies and in clinical trials of many diseases (Horwitz et al., 1999; Wakitani et al., 2004), MSC cell therapy holds great promise as a means to restore function in damaged tissues, however many concerns still need to be addressed, particularly the in-depth characterization of each stem cell type revealing their cellular phenotype, therefore their morphology and function. In this regard, a proteomic analysis, providing an overall outline of the cell's protein content needed to generate and maintain a phenotype, is necessary to better comprehend their mode of action. In this way, an appropriate utilization and targeted therapeutic potential of the stem cells is ensured. Previous studies performed a proteomic analysis of MSCs of different sources and concluded that mainly two cell types, bone marrow-MSCs and adipose derived stem cells, were very similar with however some differences difficult to pinpoint (Im et al., 2005; Izadpanah et al., 2006; Noel et al., 2008; Puissant et al., 2005; Sakaguchi et al., 2005; Wagner et al., 2005). In a recent proteomic study, we aimed at comparing human MSCs and related progenitor cells, isolated from different sources and cultured in strict controlled conditions, to human ESCs (hESCs). This study defined a common proteomic profile that distinguished hMSCs from hESCs. Moreover it permitted to delineate certain differences between MSCs from different sources (Roche et al., 2009).

We have isolated a developmentally immature and highly homogeneous subpopulation of hMSCs, termed marrow-isolated adult multilineage inducible (MIAMI) cells. These cells, typified by the sustained expression of certain embryonic stem cell markers (D'Ippolito et al., 2004, 2006a,b,c; Tatard et al., 2007), can be isolated from whole bone marrow, without the need for culture expansion. MIAMI cells can differentiate in vitro into cells found in tissues derived from all three embryonic germ layers, including neuronal-like cells exhibiting functional ionic channels (D'Ippolito et al., 2004; Tatard et al., 2007). Furthermore, MIAMI cells are capable of preventing tissue damage and promoting tissue repair and functional recovery in animal models of cerebral ischemia, Parkinson's disease, and critical limb ischemia (Delcroix et al., 2011; Garbayo et al., 2011; Rahnemai-Azar et al., 2011b). A fraction of the engrafted cells expressed features of neuronal or vascular cells, but the principal form of tissue repair seems to be the secretion of cytokines known to be involved in neuroprotection, cell survival, progenitor cell recruitment, and angiogenesis. MIAMI cells thus represent a drug delivery therapeutic product that needs to be thoroughly characterized.

In the present study we sought to analyze the proteomic profile of MIAMI cells and compare it to hMSCs and to hESCs. We further investigated the secretory profile of MIAMI cells compared to MSCs. Finally we analyzed these results taking into consideration the membrane expression profile, metabolic profile and secretory profile for a cell therapeutic product. Indeed, a therapeutic product for cell therapy should present certain characteristics like a high metabolic activity, be poorly immunogenic, a rapid turn-over of protein. These analyses are particularly relevant in the context of the beneficial impact these cells may have as living pharmacological delivery systems able to sense the health status of an injured, diseased or aged tissue or organ; and potentially respond to the tissue conditions with the appropriate set of molecular mediators to promote tissue repair. These molecular mediators could potentially exert their effects via parallel autonomous or synergistic modalities; such as contact-independent paracrine effects or contact-dependent mechanisms. As a result, these cells may regulate inflammation, apoptosis, necrosis, migration, proliferation, differentiation, aging, remodeling, and other cellular and tissue processes involved in repair.

\section{Material and methods}

\subsection{Cell cultures}

For MSCs isolation and culture, bone marrow aspirates were collected on ACD-heparin tubes (BD Bioscience, San Jose, CA) from healthy adult volunteers after informed consent. After ficoll gradient separation (GE Healthcare, Milwaukee, WI), nucleated cells were directly plated at 50,000 cells per $\mathrm{cm}^{2}$ on plastic culture dishes (Nunc, Roskilde, Denmark). Expansion medium consisted of $\alpha$-MEM basal medium (Invitrogen, Carlsbad, CA) supplemented with $10 \%$ fetal bovine serum (FBS, Invitrogen), $2 \mathrm{mM}$ glutamine (Invitrogen) and penicillin/streptomycin (Invitrogen). Two to three days later non-adherent cells were discarded and primary culture was performed for 21 days. The expansion medium was changed twice a week. After reaching subconfluence, cells were detached with $0.25 \%$ trypsin and $1 \mathrm{mM}$ EDTA (Invitrogen), suspended in fresh medium, plated at 1000 cells $/ \mathrm{cm}^{2}$ and incubated for 14 days at $37{ }^{\circ} \mathrm{C}$ in $5 \% \mathrm{CO}_{2}$ (Roche et al., 2007). MIAMI cell isolation and expansion was performed as previously described (D'Ippolito et al., 2004, 2006b). Briefly, whole bone marrow cells were plated at a constant density of $1 \times 10^{5}$ cells $/ \mathrm{cm}^{2}$ in DMEM-low glucose medium (Invitrogen), containing $3 \%$ FBS and $100 \mathrm{U} / \mathrm{mL}$ penicillin, $1 \mathrm{mg} / \mathrm{mL}$ streptomycin, $100 \mu \mathrm{M}$ ascorbic acid 2-phospahte (Sigma), and a mixed solution of essential fatty acids (Sigma, expansion medium) in fibronectin ( $10 \mathrm{ng} / \mathrm{mL}$; Sigma, St. Louis, MO)-coated 10 cm dishes (Nunc). Whole bone marrow cells, containing adherent and nonadherent cells, were maintained in a humidified incubator at $37^{\circ} \mathrm{C}$ undisturbed in an atmosphere of $3 \% \mathrm{O}_{2} / 5 \% \mathrm{CO}_{2} / 92 \%$ $\mathrm{N}_{2}$ (low oxygen); 7 days later, half of the culture medium was replaced. Fourteen days after the initial plating, the nonadherent cells were removed. Single-cell-derived and pooled colonies of adherent cells were carefully rinsed in medium and subcloned. These cells were selected and expanded at low density ( $\leq 30 \%$ confluency) by plating single-cell-derived or pooled colonies in fibronectin-coated dishes using expansion medium in low oxygen.

\subsection{Whole cell extract}

To improve the reproducibility of the analysis, we have previously published a protocol where protein extraction was performed directly in the culture dishes (Roche et al., 2009). Briefly, the cells were washed twice with PBS (Invitrogen) containing a cocktail of protease inhibitors (P8340, Sigma) then lysed directly in the culture dish with $200 \mu \mathrm{L}$ of lysing buffer ( $8 \mathrm{M}$ urea, $2 \mathrm{M}$ thiourea, $4 \% \mathrm{CHAPS}$, $50 \mathrm{mM}$ DTT; Sigma). The cell lysates were collected and stored at $-80^{\circ} \mathrm{C}$ until use. Protein concentration of the lysates was determined using the Plus-One 2-D Quant Kit (GE Healthcare) following the manufacturer's instructions. 


\section{3. $2-D E$}

As previously describe (Provansal et al., 2011), proteins were separated on the basis of two dimensions: isoelectric point and masses. For the first dimension, $30 \mu \mathrm{g}$ of proteins was added in $250 \mu \mathrm{L}$ of rehydratation buffer $(9.8 \mathrm{M}$ urea, $4 \%$ CHAPS, $50 \mathrm{mM}$ DTT, and $0.5 \%$ IPG buffer 3-10, all from Sigma). IPG strips (13 cm, GE Healthcare), covering a $\mathrm{pH}$ range of 3 to 10 were rehydrated with this solution during $9 \mathrm{~h}$ at $20^{\circ} \mathrm{C}$ covered by low viscosity paraffin oil (Sigma). For focalization, the following voltage/time profile was used: $200 \mathrm{~V}$ for $1 \mathrm{~h}, 1000 \mathrm{~V}$ for $1 \mathrm{~h}, 3000 \mathrm{~V}$ for $1 \mathrm{~h}$, a gradient between $3000 \mathrm{~V}$ and $8000 \mathrm{~V}$ during $2 \mathrm{~h}$ and $8000 \mathrm{~V}$ for $5 \mathrm{~h}$. A total of 76,000 volt-hours (Vh) was used. Focused strips were frozen at $-20^{\circ} \mathrm{C}$. For the second dimension, strips were equilibrated for $30 \mathrm{~min}$ in $6 \mathrm{M}$ urea, 30\% glycerol (Sigma), 2\% Sodium Dodecyl Sulfate (SDS, Sigma), $50 \mathrm{mM}$ Tris pH 8.8 (Sigma), 1\%DTT and then for an additional $30 \mathrm{~min}$ in the same solution except that DTT was replaced by $5 \%$ iodoacetamide (Sigma). After equilibration, proteins were separated in the second dimension by a SDS-PAGE method using $12 \%$ acrylamide gel (Sigma) with a ratio of acrylamide/bisacrylamide of 37.5:1.

\subsection{Silver staining and scan}

Gels were stained with a silver nitrate procedure (Shevchenko et al., 1996) and scanned at 300 dots per inch using the Labscan 3 software (GE Healthcare) after a procedure of calibration using the kaleidoscope LaserSoft Imaging (Kodak, Ref: R020123, Rochester, NY). Spot detection and quantitation were performed with ImageMaster 2DE Platinum (GE Healthcare) and Progenesis SameSpot softwares (Non Linear). The volume of each spot (integrated optical density) was calculated as the product of spot area and spot intensity. To take into account experimental variations, 2-D gels were normalized to the volume of all spots detected on the 2DE gel.

\subsection{Identification of protein expression and statistical test}

The quantification was performed using Progenesis SameSpot by an integration of the gray level of each spot and normalization with the total spot volume. In this method, the volume of each spot is divided by the total volume of all of the spots in the gel. Three to five replicates with independent samples were performed to ensure reproducibility of the results. For comparison, the MIAMI cell gels were used as reference.

Statistical analysis was performed using the Hierarchical Clustering Explorer 3.0 software (Seo et al., 2004), with an average linkage hierarchical clustering algorithm, using the centered Manhattan Distance coefficient as the similarity metric. Differential function analysis was analyzed through the use of Gene Ontology and UNIPROT database. The Functional Analysis identified the biological functions associated to the data set. A fold increase ratio of 2 and a $p$-value of 0.05 , calculated by Progenesis SameSpot, were used to define the limit of significance using MIAMI cells as reference (value of 1). Each differential spot was associated to its function and plot.

\subsection{Molecular weight and iso-electric point calibration}

The experimental molecular weight and pHi were obtained using a 2DE protein standard (Bio-Rad, Hercules, CA): an additional 2DE gel was performed with a mixture of $10 \mu \mathrm{g}$ of whole MSC extract and $5 \mu \mathrm{L}$ 2DE standards. Additional spots were positioned and annotated with their respective MW and $p I$. After a step of comparison with this gel, the software calibrates all homologous gels with pHi and MW.

\subsection{Protein isolation and identification by mass spectroscopy}

Protein spots were excised from coomassie stained (Sigma) 2DE gels containing $300 \mu \mathrm{g}$ of proteins. Spots were washed in $15 \mu \mathrm{L}$ of $100 \mathrm{mM} \mathrm{NH} \mathrm{NCO}_{3}$ during $10 \mathrm{~min}$. After addition of $15 \mu \mathrm{L}$ of acetonitrile (Sigma) for $10 \mathrm{~min}$, supernatants were removed and the procedure repeated. After evaporation to dryness in a benchtop Speedvac, spots were re-hydrated in $10 \mu \mathrm{L}$ of trypsin solution (15 ng/ $\mu \mathrm{L}$, Promega, Madison, WI) and digested overnight at $25^{\circ} \mathrm{C}$ in $10 \mu \mathrm{L}$ of $100 \mathrm{mM} \mathrm{NH}_{4} \mathrm{HCO}_{3}$ and $5 \mathrm{mM} \mathrm{CaCl}_{2}$ buffer (Sigma). The tryptic peptides were extracted in a two step procedure: the first step was composed by an addition of $10 \mu \mathrm{L}$ of $100 \mathrm{mM} \mathrm{NH}_{4} \mathrm{HCO}_{3}$ followed by $10 \mathrm{~min}$ of $10 \mu \mathrm{L}$ acetonitrile. This step was repeated twice and supernatants pooled. The second step was a $10 \mathrm{~min}$ incubation with $10 \mu \mathrm{L}$ of $5 \%$ formic acid (Sigma) and followed by an addition of $10 \mu \mathrm{L}$ of acetonitrile for $10 \mathrm{~min}$. This step was repeated twice and the supernatants pooled. Samples were evaporated to dryness and put back in solution in $20 \%$ formic acid and desalted on Millipore ZipTip C18 column (Millipore, Molsheim, France).

Peptide masses were determined in the positive-ion reflector mode in an Ultraflex mass spectrometer (Bruker, Madison, WI). Peptide mass fingerprints were compared to mammalian databases (SWISS PROT and Trembl) using MASCOT (http://www.matrixscience.com/cgi/search_form.pl?FORMVER=2\& SEARCH=PMF) and Aldente (http://www.expasy.org/tools/aldente/) algorithms with one missing trypsin cleavage site and a mass deviation smaller than $20 \mathrm{ppm}$. The probabilistic score of MASCOT/Aldente was required for the identification of an unnamed protein.

\subsection{Protein preparation, Western blot analysis, and quantification}

Cell pellets were resuspended in NP40 lysis buffer ( $50 \mathrm{mM}$ Tris, $1.0 \% \mathrm{NP} 40,150 \mathrm{mM} \mathrm{NaCl}, 2 \mathrm{mM}$ EGTA, $2 \mathrm{mM}$ EDTA, $50 \mathrm{mM} \mathrm{NaF}$, and $0.1 \mathrm{mM}$ NaVO4, Sigma), pH 8.0. The protease inhibitor cocktail was added ( $2 \mu \mathrm{l} / 1 \mathrm{~mL}$ lysis buffer) to NP40 lysis buffer before protein extracts were collected. Protein concentration was determined with the BCA protein assay (Pierce, Rockford, IL). Protein samples were separated by SDS-PAGE on $10 \%$ polyacrylimide gels, and then transferred onto PVDF membrane (Millipore) for approximately 60 to $90 \mathrm{~min}$ at $100 \mathrm{~V}$. Blocking solution consisted of either 2-5\% BSA (Sigma) or dried milk in Tris-buffered saline (TBS, Sigma) solution with $1-2.5 \%$ Tween 20 (Sigma). Blots were incubated with primary antibodies overnight at $4{ }^{\circ} \mathrm{C}$ with gentle rocking, rinsed with TBS, and with secondary antibodies for $45 \mathrm{~min}$ at room temperature with gentle rocking. UCHL1 antibody was from Abcam (ab72911; Cambridge, MA), 14-3-3 antibody from Santa Cruz Biotechnology (K19; Santa Cruz, CA) and HSP27 from Cell Signaling Technology (\#2442; Danvers, MA). Protein levels were normalized to $\alpha$-tubulin and/or Coomassie blue-stained membranes. Quantitation of blots was performed using Image software from NIH (Reiner et al., 2009).

For 2D Western blotting, the first dimension of the 2DE was performed using a $7 \mathrm{~cm}$ IEF strip (Invitrogen). The only modification in the protocol (when compared to the $13 \mathrm{~cm}$ IEF strip) was the lower volume of samples ( $125 \mu \mathrm{L})$ and IPG buffer $(0.5 \mu \mathrm{L})$ used. The second dimension was performed with the NuPAGE system (Invitrogen) with one well Bis/Tris $12 \%$ gels. For 1D Western blotting, the electrophoresis was performed as described in the manufacturer instruction. At the end of the migration, the proteins were transferred on a PVDF membrane using the X Cell Blot system (Invitrogen) as per the manufacturer instruction. At the end of the transfer, the membrane was incubated in the blocking buffer during $30 \mathrm{~min}$ and in the primary antibody dilution during $1 \mathrm{~h}$. After 4 wash with PBS $1 \times$ Tween $0.05 \%$, the membrane was incubated in the secondary antibody dilution during $1 \mathrm{~h}$. After 4 wash with PBS 
$1 \times$ Tween $0.05 \%$, the membrane was incubated with SuperSignal Mix (Thermo Scientific, Rockford, IL) during 5 min and scanned in a Bio-Rad CCD imager (Provansal et al., 2011).

\subsection{Flow cytometry analysis and Oct4 immunofluorescence}

Presence of the characteristic CD molecules expressed by MSCs and of certain embryonic stem cell markers was analyzed by flow cytometry and immunocytofluorescence (CD90, CD44, CD73, CD105, CD106, CD166, CD45, CD34, CD56, CD31, NTRK3, SSEA4). Antibodies were purchased from R\&D (Minneapolis, MN). Flow cytometry was performed essentially as previously described (D'Ippolito et al., 2004, 2006a) from cells grown and processed in triplicate.

For nuclear proteins (Oct4a, Abcam), cells were fixed with $4 \%$ paraformaldehyde (PFA, Sigma) at $4{ }^{\circ} \mathrm{C}$ for $10 \mathrm{~min}$ and permeabilized with $0.1 \%$ Triton X-100 for $10 \mathrm{~min}$. Blocking and diluent solution consisted of phosphate-buffered saline (PBS) with 1\% BSA. Fixed cells were blocked for $30 \mathrm{~min}$, incubated sequentially $1 \mathrm{~h}$ with the primary antibody to Oct 4 followed by $1 \mathrm{~h}$ incubation of the fluorescein- or rhodamine-conjugated secondary anti-goat IgG antibody. PBS plus $0.3 \%$ BSA was used for the washes between each step. Non-specific immunostaining controls were demonstrated for each experiment in which cells were exposed to primary isotypic antibodies and then incubated with conjugated secondary antibodies.

\subsection{Bioplex analysis of cytokine production}

Cells plated at a concentration of 5000 cells $/ \mathrm{cm}^{2}$ were grown for seven days in the presence of complete expansion medium. After seven days, supernatants were collected and plated into a 96 well plate assay to analyze the expression of 42 different human cytokines and chemokines (Milliplex; human cytokine/chemokines immunoassay) using the manufacturer's guidelines. Quantification of secreted factors was performed on a Bio-Plex 200 reader and Bio-Plex Pro wash stations (Bio-Rad), and analyzed with the BioPlex Manager Version 3.0 software. Data analyses were performed with Microsoft Excel 2007. All data were normalized to $1 \times 10^{6}$ cells.

Quantitative bioplex data are expressed as mean \pm SEM. Statistical analysis was performed using a parametric one-way ANOVA and Newman-Keuls multiple comparison test. A value of $p \leq 0.05$ was considered statistically significant.

\section{Results}

\subsection{Cell morphology and phenotypic analysis}

Human mesenchymal stem cells had the typical fibroblastic morphology with few long and thin cell processes, while MIAMI cells appeared to be smaller in size with a smaller and more rounded cytoplasm (Fig. 1A and B). Undifferentiated hESCs had the classical tightly packed rounded shape with high nucleus/cytoplasm ratio and the colonies showing clear margins (Fig. 1C). The ability of the marrow-derived cells to differentiate into adipocyte, osteoblast, and chondrocyte lineages was experimentally confirmed before proteomic and phenotypic analyses (data not shown). The classical human MSC phenotype $\left(\mathrm{CD}^{+}, \mathrm{CD}^{+} 3^{+}, \mathrm{CD} 105^{+}, \mathrm{CD} 44^{+}\right.$, and $\left.\mathrm{CD} 45^{-}\right)$ was validated for hMSC. MIAMI cells also exhibited expression of these CD markers. As expected, hESC had a phenotypic pattern characterized by the absence of CD73 and CD105 and the expression of early development markers stage-specific embryonic antigen-4 (SSEA-4) and the self-renewal transcription factor Oct4a (Table 1). The strong surface expression of SSEA-4 and nuclear localization of Oct4a in MIAMI cells clearly distinguished them from hMSCs
Table 1

Phenotypes of the stem cells.

\begin{tabular}{|c|c|c|c|}
\hline & hMSC & MIAMI & hESC \\
\hline CD90 & ++ & ++ & ++ \\
\hline CD44 & ++ & ++ & ++ \\
\hline CD73 & ++ & ++ & - \\
\hline CD105 & ++ & ++ & - \\
\hline CD106 & ++ & ++ & - \\
\hline CD166 & ++ & ND & ++ \\
\hline CD45 & - & - & - \\
\hline CD34 & - & - & - \\
\hline CD56 & - & - & - \\
\hline CD31 & - & - & - \\
\hline NTRK3 & - & ++ & ND \\
\hline SSEA-4 & $-/+$ & ++ & ++ \\
\hline Oct4a & - & ++ & ++ \\
\hline
\end{tabular}

Expression of various markers was tested by flow cytometry (++ strongly positive, + positive, -/+ marginal, - negative, ND not done).

and established relevant phenotypic differences between these two post-natal BM-derived cell types. Additionally, surface expression of the neurotrophin tyrosine kinase receptor type III (NTRK3) contributed to further distinguish MIAMI cells from hMSCs (Table 1 and Supplementary Fig. 1).

Supplementary material related to this article found, in the online version, at doi:10.1016/j.ijpharm.2011.12.041.

\subsection{Proteomic analysis}

The primary human hMSCs were used to generate a human stem cell master gel as previously described (Roche et al., 2009) (Supplementary Fig. 2). Since calculated pHi and MW are not reliable parameters following 2-DE, the master gel was calibrated using purified proteins. Cytoplasmic and nuclear proteins were identified, as well as proteins from mitochondrion, endoplasmic reticulum and membrane. Post-translationally modified proteins (which were detected as multiple spots) belonged mainly to cytoplasmic and ER compartments, rather than to the mitochondrion and the nucleus. Extracts from the different stem cell populations were used to carry 2-DE gels as illustrated in Fig. 1(D-F). Following a thorough analysis using Progenesis SameSpot (Supplementary Table 1) and the Hierarchical Cluster Explorer software, different stem cell proteomic clusters were detected (Fig. 2A). Manhattan distance statistical tests indeed revealed the presence of 2 main clusters: one including MIAMI and hMSCs; the second one composed of hESC. Interestingly, hMSC and MIAMI cells were closely related in this analysis. The variability of the spots between replicates for most stem cells was close to $30 \%$, which was satisfactory. Spots with significant modified expression were selected based on increased or decreased expression by a factor of 2 or a $p$-value inferior at 0.05 . The $p$-value was calculated by 2 methods, $t$-test in order to compare each type of cell to hMSC, and ANOVA to compare all stem cells together. Protein match between MIAMI vs. hMSCs was $62 \% \pm 3 \%$ and between MIAMI vs. hESCs was $53 \% \pm 5 \%$. Changes in protein expression levels between MIAMI vs. hMSCs were $24 \%$ increased and $10 \%$ decreased; between MIAMI vs. hESCs the change was 38\% increase and 7\% decrease. It is interesting to note that Identified proteins in the master gel were involved in a large range of functions including: signal transduction, intracellular trafficking, glycolysis, metabolism, folding, protein biosynthesis and proteolysis (Fig. 2B). This result allows us to perform a thorough characterization and comparison of the cells.

Supplementary material related to this article found, in the online version, at doi:10.1016/j.ijpharm.2011.12.041. 

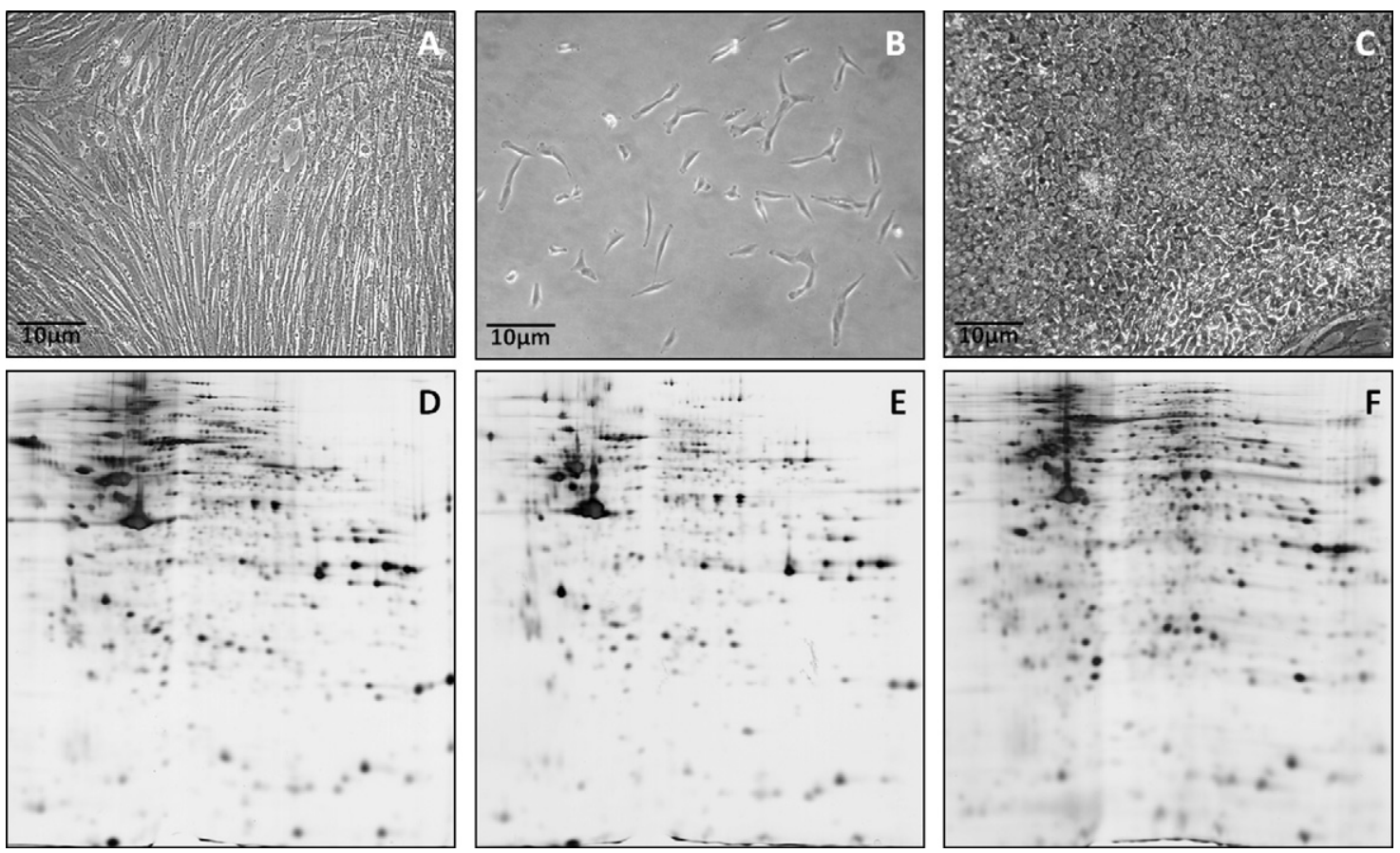

Fig. 1. Morphology and 2DE profile of cells. (A) Human mesenchymal stem cells had the typical fibroblastic morphology with few long and thin cell processes. (B) MIAMI cells appeared to be smaller in size with a smaller and more rounded cytoplasm. (C) Undifferentiated hESCs had the classical tightly packed rounded shape with high nucleus/cytoplasm ratio and the colonies showing clear margins. Representative 2DE gels of the different cultures. Whole cell extracts (30 $\mu \mathrm{g})$ were separated using $2 \mathrm{DE}$ electrophoresis in a dry strip pH 3-10 for the first dimension and a 12\% SDS-PAGE for the second and silver stained. The gel is representative of 3-4 gels from independent cultures samples performed before statistical analysis. (D) 2DE master gel of bone marrow-derived hMSCs. For the identification of proteins, noted with their serial number was performed by peptide mass fingerprints after trypsin digestion and MALDI-TOF on Coomassie stained spots see Supplementary Fig. 1. (E) 2DE gel of bone marrow-derived human MIAMI cells. (F) 2DE gel of hESCs.
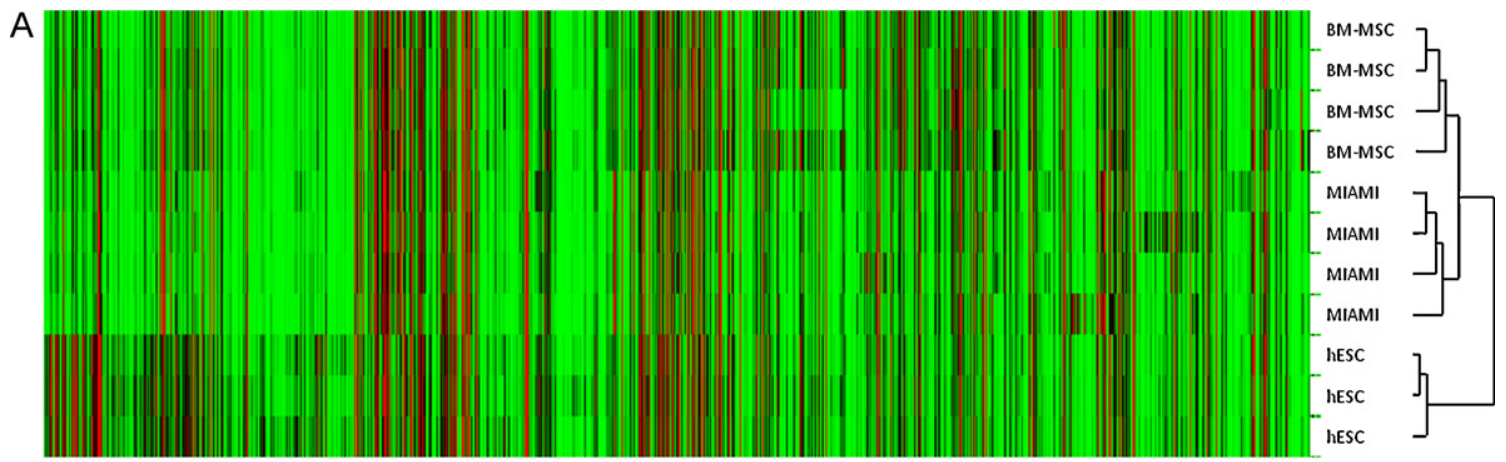

B

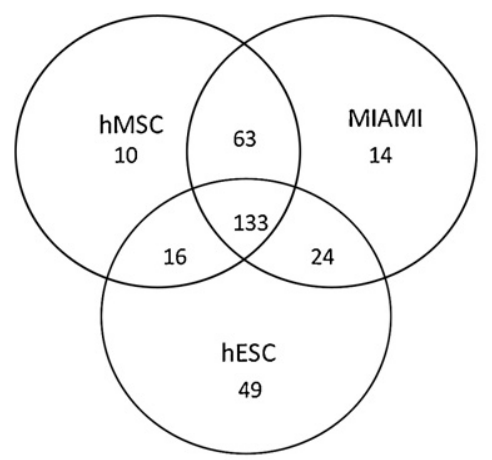

C

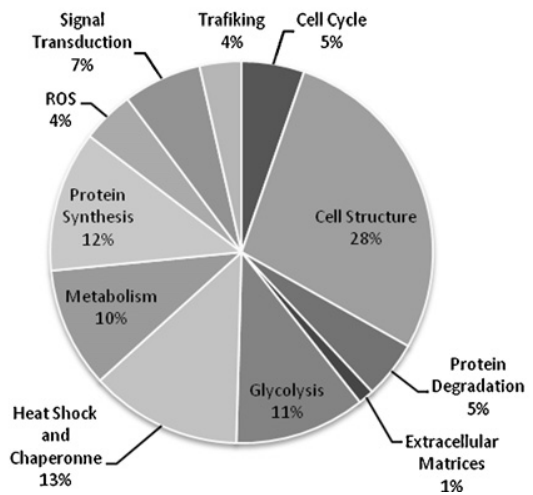

Fig. 2. Characterization of the proteome of the different stem cell populations. (A) Hierarchical clustering of the 2DE data. Data from hMSCs, MIAMI cells and hESCs have been generated by comparison, quantification and normalization of the different 2DE gel using Progenesis SameSpot. Clustering was performed using the Hierarchical Clustering Explorer version 3 software with Manhattan Distance as statistical test. (B) Common and significantly different 2-DE proteins. The numbers correspond to the spots of proteins in common or significantly different between hMSC, MIAMI and hESC. (C) Pie chart of protein function represented in the 2D gel of hMSC, MIAMI cells and hESCs. All Proteins identified were distributed between functional blocks using the SwissProt (http://www.expasy.org/) and the Gene Ontology (http://www.geneontology.org/) databases. The block plotted here are "Cell Cycle" (12 protein spots), "Cell Structure" (63 protein spots), "Proteolysis" (11 protein spots), “Extracellular Matrices" ( 3 protein spots), "Glycolysis" (25 protein spots), "Heat Shock and Chaperone" (29 protein spots), "Metabolism” (23 protein spots), "Protein Biosynthesis" (27 protein spots), "ROS and Energy" (10 protein spots), “Signal Transduction” (15 protein spots), "Intracellular Trafficking” (8 protein spots). 
Table 2

Common and significantly different 2-DE proteins expressed by MSCs, ESCs and MIAMI cells.

\begin{tabular}{|c|c|c|c|c|c|c|}
\hline \multicolumn{7}{|c|}{ Proteins that are expressed at higher levels in MIAMI cells compared to MSCs and ESCs } \\
\hline \multirow[t]{2}{*}{ ID } & \multirow[t]{2}{*}{ Protein information } & \multirow[t]{2}{*}{ Accession number } & \multicolumn{2}{|c|}{ hMSCs } & \multicolumn{2}{|c|}{ hESCS } \\
\hline & & & Fold & $t$-Test $(p)$ & Fold & $t$-Test $(p)$ \\
\hline 1282 & Ubiquitin carboxyl-terminal hydrolase & UCHL1_HUMAN & -2.6 & 0.031 & -1.1 & 0.649 \\
\hline 526 & 14-3-3 zeta/delta spot & P63104 & -2.2 & 0.037 & -1.8 & 0.049 \\
\hline 1290 & $14-3-3$ zeta/delta spot 1 & P63104 & -1.9 & 0.044 & -1.9 & 0.036 \\
\hline 557 & $26 S$ protease regulatory subunit 7 & P35998 & -2.0 & 0.000 & -1.9 & 0.001 \\
\hline 1215 & Lectin, galactoside-binding, soluble, 3 spot 1 & Q86TY5_HUMAN & -1.8 & 0.029 & -5.3 & 0.013 \\
\hline 507 & Tropomyosine 4 and Tropomyosine 3 & P67936 & -1.7 & 0.000 & -2.2 & 0.000 \\
\hline 1285 & HSP27 (HSP $\beta 1)$ & P04792 & -1.4 & 0.141 & -2.8 & 0.017 \\
\hline \multicolumn{7}{|c|}{ Proteins that are expressed at lower levels in MIAMI cells compared to MSCs and ESCs } \\
\hline \multirow[t]{2}{*}{ ID } & Protein information & Accession number & \multicolumn{2}{|c|}{ hMSCs } & \multicolumn{2}{|c|}{ hESCs } \\
\hline & & & Fold & $t$-Test $(p)$ & Fold & $t$-Test $(p)$ \\
\hline 3 & Transgelin-2 & P37802 & 18.8 & 0.003 & 9.1 & 0.000 \\
\hline 2 & Phosphatidylethanolamine-binding protein 1 & P30086 & 7.8 & 0.000 & 21.8 & 0.005 \\
\hline 32 & Heat shock protein beta- 6 & HSPB6_HUMAN & 6.5 & 0.000 & 9.0 & 0.029 \\
\hline 174 & Prolyl 3-hydroxylase 3 & Q7L2T1 & 4.6 & 0.049 & 2.7 & 0.003 \\
\hline 206 & Dihydropyrimidinase-related protein 3 spot 2 & DPYL3_HUMAN & 4.1 & 0.004 & 3.9 & 0.001 \\
\hline 210 & Alpha-actinin-1 & P12814 & 3.3 & 0.049 & 3.0 & 0.001 \\
\hline 1141 & Programmed cell death 6-interacting & PDC6I_HUMAN & 3.0 & 0.002 & 1.6 & 0.140 \\
\hline \multicolumn{7}{|c|}{ Proteins that are expressed at higher levels in hESCs compared to MSCs and MIAMI cells } \\
\hline \multirow[t]{2}{*}{ ID } & \multirow[t]{2}{*}{ Protein information } & \multirow[t]{2}{*}{ Accession number } & \multicolumn{2}{|c|}{ hMSCs } & \multicolumn{2}{|c|}{ hESCs } \\
\hline & & & Fold & $t$-Test $(p)$ & Fold & $t$-Test $(p)$ \\
\hline 1274 & GMP synthase & P49915 & 1.8 & 0.022 & 8.2 & 0.003 \\
\hline 188 & ATP Synthase D & 075947 & 2.0 & 0.017 & 4.5 & 0.000 \\
\hline 282 & Fuse Binding Protein 2 spot 1 & Q5U4P6 & 1.6 & 0.033 & 3.6 & 0.002 \\
\hline 285 & Poly(rC)-binding protein spot 1 & PCBP1_HUMAN & 1.4 & 0.049 & 3.5 & 0.000 \\
\hline 347 & Fascin & Q16658 & 1.5 & 0.023 & 3.2 & 0.017 \\
\hline 450 & Peroxiredoxin-1 & Q06830 & 1.1 & 0.688 & 2.6 & 0.000 \\
\hline 448 & Elongation factor $\mathrm{Tu}$ & EFTU_HUMAN & -1.2 & 0.309 & 2.2 & 0.002 \\
\hline \multicolumn{7}{|c|}{ Proteins that are expressed at lower levels in hESCs compared to MSCs and MIAMI cells } \\
\hline \multirow[t]{2}{*}{ ID } & \multirow[t]{2}{*}{ Protein information } & \multirow[t]{2}{*}{ Accession number } & \multicolumn{2}{|c|}{ hMSCs } & \multicolumn{2}{|c|}{ hESCs } \\
\hline & & & Fold & $t$-Test $(p)$ & Fold & $t$-Test $(p)$ \\
\hline 1271 & Lamin A/C spot3 & LMNA_HUMAN & 1.4 & 0.024 & -3.3 & 0.003 \\
\hline 155 & Caldesmon spot 2 & CALD1_HUMAN & 1.5 & 0.027 & -3.2 & 0.011 \\
\hline 1203 & Annexin A2 1 spot & P07355 & -1.2 & 0.216 & -6.9 & 0.008 \\
\hline 1242 & Annexin A2 spot 2 & ANXA2_HUMAN & -1.3 & 0.027 & -4.6 & 0.000 \\
\hline 1202 & Annexin A2 spot 3 & P07355 & -1.2 & 0.148 & -4.1 & 0.001 \\
\hline 1285 & HSP27 Beta 1 spot 1 & P04792 & -1.4 & 0.141 & -2.8 & 0.017 \\
\hline
\end{tabular}

\subsection{Comparative analyses of hMSC vs. MIAMI cells and hESCS}

To illustrate differences in proteomic patterns, the number of common and significantly different spots between hMSCs, MIAMI cells, and hESCs were computed. From this general analysis, hMSCs and MIAMI cells appeared closer with a high percentage of common spots (66.4\%) and a low number of cell specific ones (hMSCs: $3.6 \%$, MIAMI cells: $8.6 \%$ ). hMSC and MIAMI cells had also more spots in common (2.4-4-fold) than either cell type compared with hESCs. When MIAMI cells were compared to hMSCs and hESCs, a high number of spots were present in only one cell type. As expected, hESCs were more apart than hMSCs and MIAMI cells. Importantly, these differences for detected spots were also analyzed at the level of identified proteins (Fig. 2C). It confirmed the similar identity between hMSCs and MIAMI cells, their difference from hESCs as well as the higher similarity between MIAMI cells and ESCs than between hMSCs and ESCs. It was also possible to group cell-specific proteins and common proteins to hMSCs and MIAMI cells (MSC-like cells). Furthermore, the level of expression of these proteins was assed permitting us to identify certain interesting proteins that are differently expressed in MIAMI cells and in hESCs (Table 2). Identified proteins that were characteristic for MIAMI cells included ubiquitin carboxyl-terminal hydrolase isoenzyme L1 (UCHL1), 40S ribosomal protein S12, 14-3-3 zeta, and tropomyosin 4 and 3 (Table 2). Interestingly, heat-shock protein $27 \mathrm{kDa}$ (HSP27/HSP $\beta 1)$ a protein found to be characteristic of hMSCs (Roche et al., 2009) was expressed at higher levels in MIAMI cells compared to hMSCs (Table 2, Fig. 3I-M). In contrast, proteins characteristic of hMSCs included transgelin-2, phosphatidylethanolamine-binding protein 1 (PEBP1), HSP $20 \mathrm{kDa}$ (HSP20/HSP 36$)$, and programmed cell death 6 -interacting protein (PDC6I) among others (Table 2, Fig. 3A-H).

Western blot analysis was used to confirm the different expression patterns of some of the characteristic proteins. The expression of HSP27 and UCHL1 was higher in MIAMI cells compared to hMSC and hESCs (Fig. 3, bottom). In contrast, levels of protein 14-3-3 appeared to be higher in hESCs and MIAMI compared to hMSCs (Fig. 3, top).

\subsection{Functional block analysis}

MIAMI cells and hMSC were closer using functional block analysis (Fig. 4). The blocks "Cell Cycle", "Heat shock and Chaperone", "Metabolism", "Glycolysis", "ROS and Energy" and "Intracellular Trafficking" were very similar between hMSC and MIAMI cells, with less than $12.5 \%$ of spots significatively modified. "Proteolysis" and "Signal Transduction" were modified in both hMSCs and MIAMI 

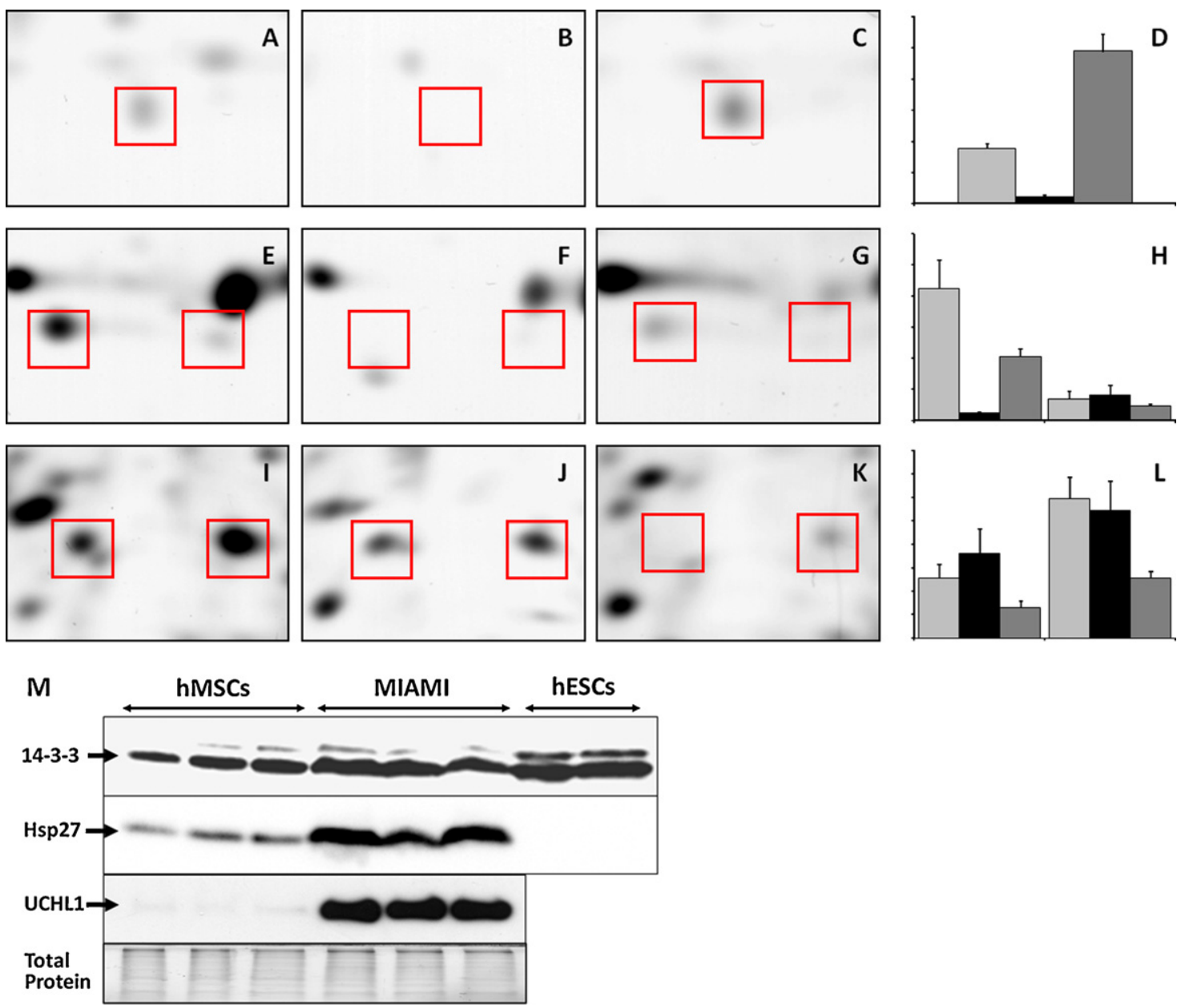

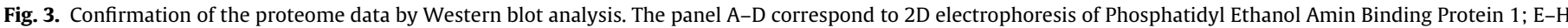

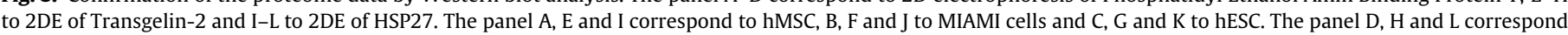

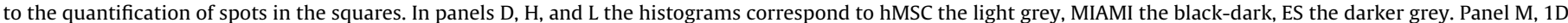

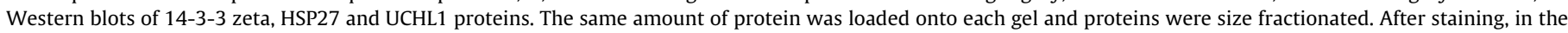

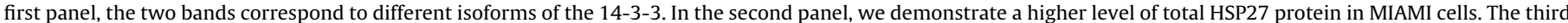

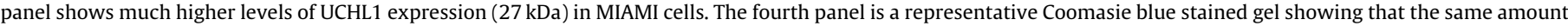

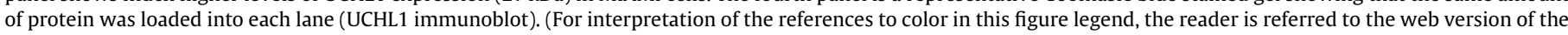
article.)

cells, with more than $25 \%$ of significatively modified spots. When we compared MIAMI and hESCs, only one group has less than $20 \%$ of proteins significatively modified and it was the "Signal Transduction" block. Interestingly, in most groups, an increase of protein amounts has been measured, for both hMSCs and ESCs vs. MIAMI cells. Generally, we noted that the proteins overexpressed in hMSCs were not the proteins overexpressed in hESCs.

\subsection{Secretory profile of adult marrow stromal stem cells}

Bio-Plex analysis of secreted chemokines, interleukins and growth factors indicates that MIAMI cells expanded at low oxygen tension $\left(3 \% \mathrm{O}_{2}\right)$ secrete several factors at higher levels compared to hMSCs expanded in air $\left(21 \% \mathrm{O}_{2}\right)$ (Fig. 5). Among the factors identified, MIAMI cells secreted higher levels of fractalkine, a chemokine with anti-apoptotic and proliferative effects on vascular cells (Liu and Jiang, 2011); IL-8, another angiogenic/arteriogenic chemokine that is produced mainly by macrophages and epithelial and endothelial cells (Martin et al., 2009); IL-6, a cytokine that has both pro-inflammatory and anti-inflammatory responses (Hurst et al., 2001; Xing et al., 1998); and the main angiogenic factor VEGF (Fig. 5). We also assessed the expression of angiostatic cytokines known to inhibit neovascularization (Ruegg et al., 2006), including IL-12, tumor necrosis factor (TNF), interferon (IFN)- $\alpha$ and C-X-C motif ligand 10 (CXCL10). We did not detect the production of these chemokines by MIAMI cells under any growth or treatment conditions examined (data not shown).

\section{Discussion}

In the present study we first determined the proteomic profile of MIAMI cells, hMSCs and hESCs analyzed by 2-DE. We generated a thorough proteomic analysis of human primary MIAMI cells followed by the comparison to hMSCs and subsequently to pluripotent hESCs. The main goal of this study was to investigate the proteomic and secretory profile of MIAMI cells and compare them to hMSCs. These analyses are particularly relevant to characterize the efficacy of these cells as living pharmacological delivery systems. These systems differ from the typical drug delivery vectors as they are able to sense the health status of an injured, diseased or aged tissue or organ and respond to the tissue conditions with the production of appropriate set of molecular mediators to promote tissue repair.

In previous studies we reported the detailed proteomic analyses of several MSC-like post natal cells in an effort to identify a 


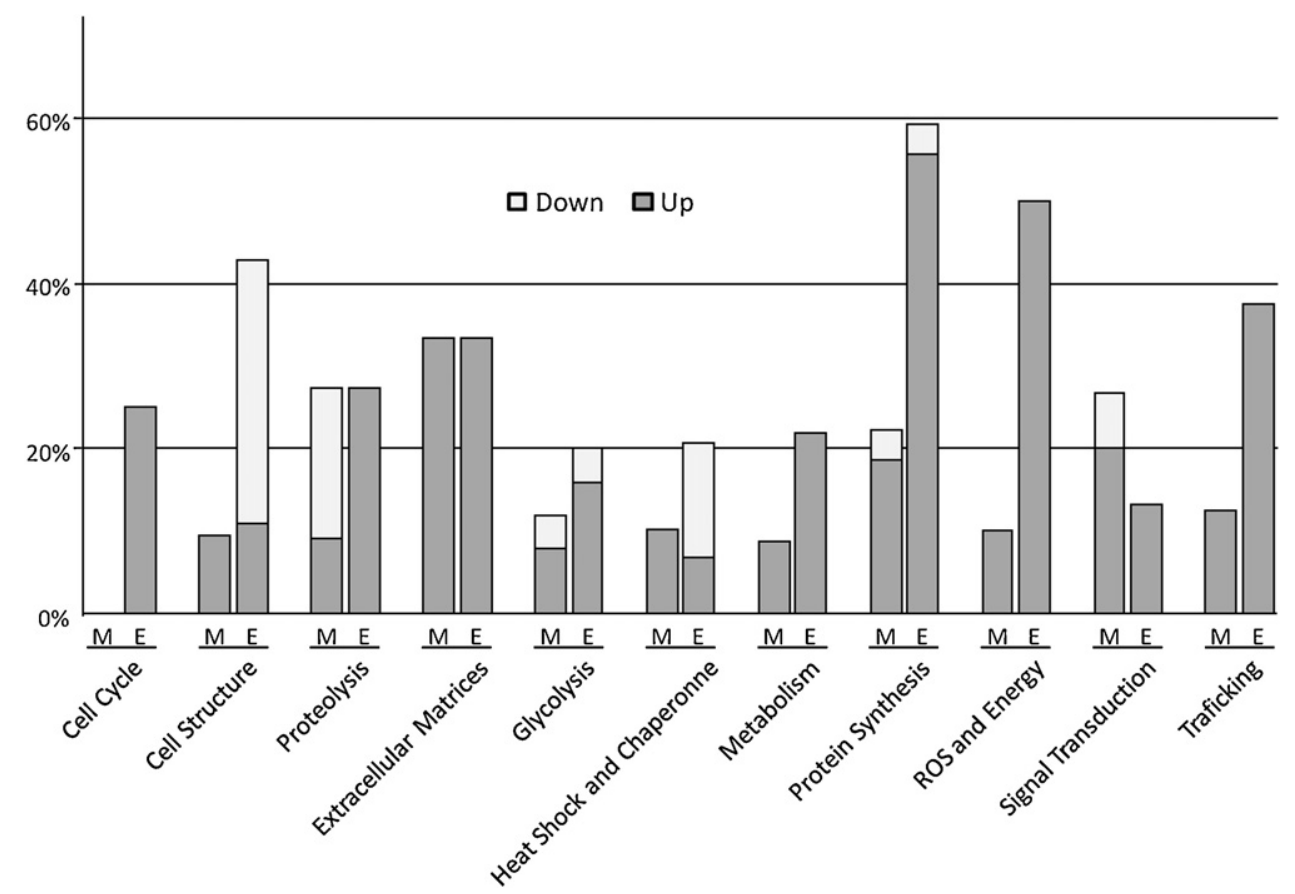

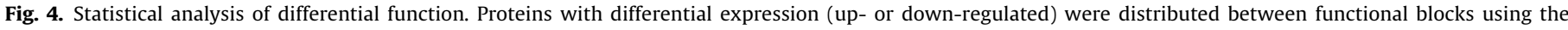

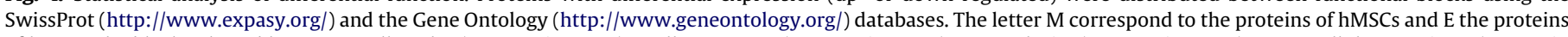

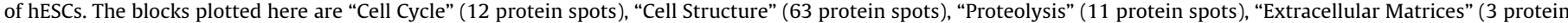

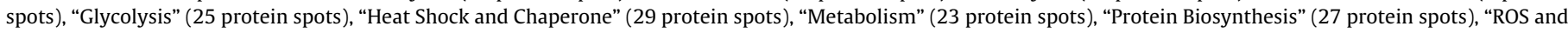
Energy" (10 protein spots), “Signal Transduction" (15 protein spots), “Intracellular Trafficking” (8 protein spots).

characteristic proteomic signature defining hMSCs (Roche et al., 2009). After comparing the proteomic profile of hMSCs with those of adipose- and synovial membrane-derived stem cells we selected annexin A1 and A2 (ANXA1 and ANXA2) and HSP27 (HSP 31 ) as markers characteristic of hMSCs. For hESC, elongation factor Tu (EFTu), isocitrate dehydrogenase (IDH1) and the peroxiredoxin 1,2 , and 6 (PRDX1, PRDX2, and PRDX6) were the most interesting ones. The molecular membrane profile, hierarchical clustering, number

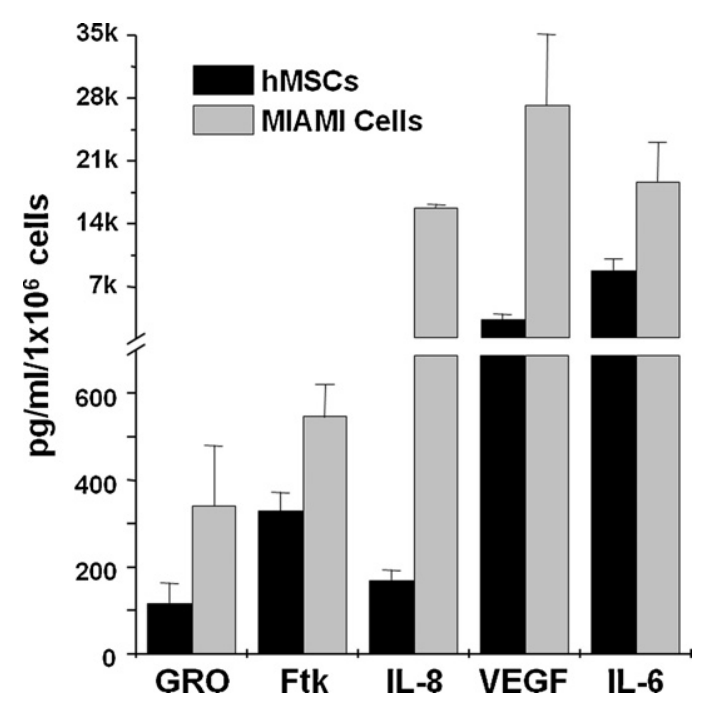

Fig. 5. Quantification of soluble factors secreted by bone marrow cells. Bio-Plex comparison of cytokine and growth factor production between MIAMI cells and hMSCs. MIAMI cells and hMSCs plated at a concentration of 5000 cells $/ \mathrm{cm}^{2}$ were grown for seven days at $3 \% \mathrm{O}_{2}$ (MIAMI cells) and $21 \% \mathrm{O}_{2}$ (hMSCs). Bio-Plex analysis was performed using supernatant collected from each single treatment. Supernatant was transferred into 96 wells plate to analyze 42 different human cytokines and chemokines. Five of them showed significant production and differences, GRO (CXCL1-3), Fractalkine (CX3CL1), IL-8 (CXCL8), VEGF, and IL-6, $p \leq 0.05$. of proteins and functional block analysis show that MIAMI cells and hMSC are more similar to each other compared to hESCs, which show more differences. Indeed, both of these adult stem cells share the same postnatal anatomical origin and present a similar phenotype, therefore showing a similar protein content. However, more similarities between MIAMI cells and hESCs were found, compared to hMSCs and hESCs. This closer phenotype between MIAMI cells and hESCs may have to do with the expression of transcription factors associated with hESC self-renewal (Oct4a, Sox2, Nanog), in addition to other proteins, in MIAMI cells. Thus, this closer phenotype may place MIAMI cells at an earlier developmental stage with a potentially broader differentiation and secretory capacity, compared to hMSCs. In contrast, compared to hESCs, MIAMI cells show a more controlled proliferative capacity, which is reflected in the functional block analysis.

In our current proteomic analysis we not only determined that hMSCs and MIAMI cells are more similar to each other compared to hESCs, which show more differences but, we further identified specific proteins which distinguish hMSCs from MIAMI cells. These include expression of transgelin-2, PEBP1, HSP20/HSP $\beta 6$, and PDC6I, among others. Transgelins are actin cross-linking proteins present in muscle and non-muscle cells, predominant in smooth muscle cells. Similarly, HSP20/HSP 36 is associated with actin and modulates smooth muscle relaxation (Tessier et al., 2003). PEBP1 appears to function as a physiologic inhibitor of $G$ proteindependent receptor kinase 2 (GRK2) to which it associates after dissociating from Raf1 in response to $G$ protein-coupled receptor stimulation (Lorenz et al., 2003). This suggests that hMSCs may have a distinct cytoskeletal organization and capacity to respond to activators of $G$ protein-coupled receptors. In this way these cells may sense, and potentially respond to, environmental cues in a distinctive fashion. Within this line, functional block analysis indicates lower levels of cell structure protein expression in hESCs, suggesting that hESCs are quite distinct in this regard while MIAMI cells and hMSCs are more similar to each other. 
In contrast, MIAMI cells can be distinguished from hMSCs by the expression of specific proteins, which distinguish MIAMI cells from hMSCs and also from hESCs. These include UCHL1, 14-3-3 zeta, tropomyosin 4 and 3, and higher levels of HSP27 expression. UCHL1 is a member of a gene family whose products hydrolyze small C-terminal adducts of ubiquitin to generate the ubiquitin monomer. Expression of UCHL1 is highly specific to neurons and cells of the neuroendocrine system. The ligase and hydrolase activities of UCHL1 may play roles in proteosomal protein degradation, a process critical for neuronal health. UCHL1 may insure ubiquitin stability within neurons (Osaka et al., 2003) thus possibly preventing neuronal death and neurodegenerative diseases. UCHL1 dysfunction is involved in the pathogenesis of Parkinson's and Alzheimer's diseases (Maraganore et al., 2004; Setsuie and Wada, 2007). This finding may suggest a greater proteosome function and survival capacity in an injured tissue microenvironment by MIAMI cells. In this regard, functional block analysis data suggests more protein turnover in MIAMI cells compared to hMSCs. 143-3 zeta belongs to a family of highly conserved proteins found both in plants and mammals. It is widely expressed in various gray matter brain regions including the neocortex, hippocampus, caudate-putamen, thalamus, cerebellar cortex, and several brain stem nuclei. It appears to play multiple metabolic roles as a modulator protein, such as a regulatory role in insulin signaling (Ogihara et al., 1997), in increasing $\beta$-catenin stabilization leading to enhanced $\beta$-catenin-dependent transcription (Tian et al., 2004), and also has been shown to have phospholipase A2 activity (Zupan et al., 1992). Tropomyosins are proteins that were first isolated from skeletal muscle, but later identified in many nonmuscle tissues. In skeletal muscle, tropomyosin isoforms are components of the thin filaments of the sarcomere and mediate the effect of calcium on the actin-myosin interaction. In non muscle cells they are part of the stress fibers which stabilize the cell structure, produce force, and transduce mechanical information about the composition of the cell exterior to drive changes in cell shape and ECM remodeling. This may contribute to a distinct cytoskeleton configuration in MIAMI cells and a better mechanical homeostasis, which may present an advantage for proper cell engraftment.

Interestingly, HSP27 (HSP $\beta 1$ ) was strongly expressed in MIAMI cells and at higher levels compared to hMSCs (Fig. 3I-M). HSP27 was originally identified as a protein mediating acquisition of thermotolerance (Landry et al., 1989) primarily by binding to and preventing misfolding of intracellular proteins. More recently, novel roles for HSP27 have been identified, including prevention of senescence (Liu et al., 2010), neuroprotection (Latchman, 2005; O'Reilly et al., 2010), immunomodulation (Banerjee et al., 2011), and atheroprotection (Rayner et al., 2010). Surprisingly, some of these novel functions take place after secretion of HSP27 into the extracellular fluid or after administration as a soluble factor (Banerjee et al., 2011; Laudanski et al., 2007; Rayner et al., 2008, 2010). This exciting novel finding invites to suggest that a potential mechanism by which MIAMI cells in particular, and perhaps hMSCs, contributes to tissue repair is by secretion of HSP27 leading to atheroprotection, neuroprotection and reduced inflammatory response (immunomodulation). Furthermore, it also suggests that MIAMI cells appear to be more protected from senescence than hMSCs, which may contribute to a stronger engraftment and production of soluble reparative mediators within an injured tissue microenvironment. However, unequivocal demonstration of the functional roles of HSP27 in MIAMI cell reparative capacity is needed; ongoing experiments will help establish them. In this regard, functional block analysis suggests that hESCs appear different to hMSCs and MIAMI cells, characterized by decreased levels of heat-shock and chaperon protein expression. In addition to the proteins herein described, which are expressed at significantly high levels, there are significant differences in the expression of other key proteins, including transcription factors (i.e., Oct4a, Sox2, Nanog), telomere length maintenance proteins (i.e., hTeRT) and cell surface markers (i.e., SSEA-4) typical of hESCs (D'Ippolito et al., 2004, 2006a; Rahnemai-Azar et al., 2011a) which would be very difficult to detect using the 2DE proteomic approach.

The secretory profiles of MIAMI cells and hMSCs demonstrate that a number of cytokines and growth factors are commonly secreted by these cells. However, some of these are expressed at significantly different levels (Fig. 5). Growth-related oncogene (GRO), a potent angiogenic chemokine also involved in stem/progenitor cells recruitment (Gordon et al., 2009; Kocher et al., 2006), was secreted at 2-fold higher levels by MIAMI cells. Fractalkine, a chemokine with anti-apoptotic and proliferative effects on vascular cells (Liu and Jiang, 2011) and mediating neuroprotection and neuromodulation in the brain (Lauro et al., 2008, 2010; Re and Przedborski, 2006), secretion was 2-fold higher. IL-6, a cytokine that has both pro-inflammatory and anti-inflammatory responses (Hurst et al., 2001; Xing et al., 1998) was secreted at about 3fold higher levels; while IL-8, another pro-inflammatory molecule which is also an angiogenic/arteriogenic chemokine (Martin et al., 2009) which is also known to promote proliferation and inhibit apoptosis in cells expressing CXCR1 and/or CXCR2 chemokine receptors (Singh and Lokeshwar, 2009) was also secreted at higher levels. The latter was secreted more than 90 -fold higher in MIAMI cells. The high secretion level of these pro-inflammatory molecules requires careful attention; however, it should be noted that injection of MIAMI cells into critically ischemic limbs dramatically reduced inflammation, necrosis and leukocyte infiltration (Rahnemai-Azar et al., 2011b)

Adult stem cells may indeed be able to monitor the microenvironment and respond to specific cues provided by their surroundings. In this way, they may produce different factors at different moments depending on the physiological status of the lesion and the way it evolves. Although it is a unique and potentially interesting quality, it is still not clear if this property would be beneficial for tissue repair. At this point, we observe that the cells do not thrive and survive/differentiate in the lesion site which is hostile for the cell leading primarily to cell death. An alternative strategy is to co-deliver a controlled cytokine release device that modifies the cell microenvironment at the time of transplantation providing the appropriate cues to enhance their engraftment and regenerative potential. Furthermore, the delivery of cytokines on their own by the controlled release device may partially mimic the cellular effects or alternatively enhance the endogenous cell ability to respond to injury signals and direct tissue repair in the absence of the transplanted cells. Nevertheless, there are limitations to either strategy, such as releasing the therapeutic mediator at the appropriate dose and time, or sequentially in concert with additional therapeutic mediators. Finally, as stem cells home to the site of injury/disease, they may be more efficient in responding to the insults due to disease/injury and will be definitely less toxic than systemic injection of cytokine.

In summary, these data suggest that different post-natal progenitor/stem cell subpopulations isolated from human bone marrow may contribute to tissue repair and regeneration in different fashions. These contributions will depend on several factors and may rely in particular on the cellular proteomic composition, which will in turn determine the cell structure, membrane properties, metabolic capacity, tolerance to stress, and capacity to sense and respond to tissue injury signals. Consequently, key secreted factors playing central roles in various aspects of tissue repair, including recruitment of host stem cells, angiogenesis, arteriogenesis, immunomodulation (reduction of inflammation), neuroprotection, neuromodulation, cell proliferation, cell survival (anti-apoptosis), and wound healing, among others, would likely be secreted at different levels. As we here demonstrate, compared to hMSCs, MIAMI 


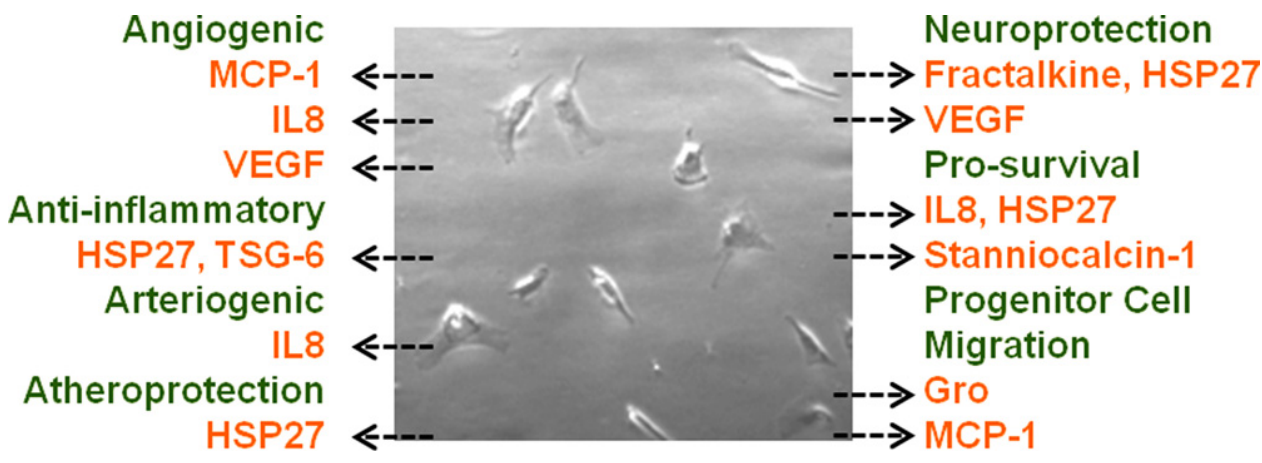

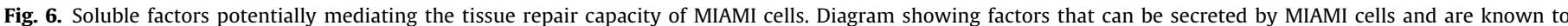

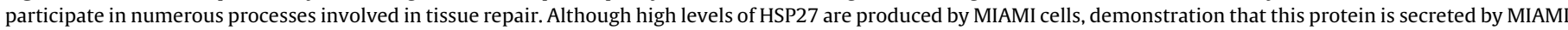

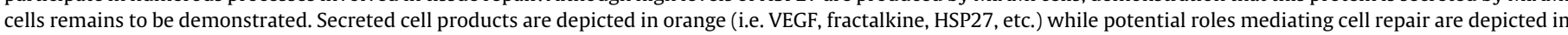
green (i.e., neuroprotection, progenitor cell migration, etc.).

cells secrete 2 - to $>90$-fold higher levels of specific molecular mediators involved in all these therapeutic functions (Fig. 6). However, secreted soluble factors may not be the only mechanism by which these infinitesimal pharmacological factories deliver their therapeutic molecules. Cell-to-cell contact mechanism may also be employed. These mechanisms could potentially involve signaling via cell adhesion molecules (Zhong and Rescorla, in press), cellcontact mediated signaling (i.e., notch) (Aguirre et al., 2010), or gap-junction channels (Jaderstad et al., 2010) which may allow for the transfer of small regulatory molecules (i.e., microRNAs) between adjacent cells (Katakowski et al., 2010).

\section{Acknowledgments}

We would like to thank the Department of Veterans Affairs, USA, for partly supporting these studies via Merit Review awards (PCS) and the European Community (Key action LSH 1.2.4-3, Integrated project: "Adult mesenchymal stem cells engineering for connective tissue disorders; From the bench to the bed side", GENOSTEM).

\section{References}

Aguirre, A., Rubio, M.E., Gallo, V., 2010. Notch and EGFR pathway interaction regulates neural stem cell number and self-renewal. Nature 467, 323-327.

Banerjee, S., Lin, C.F., Skinner, K.A. Schiffhauer, L.M., Peacock, J., Hicks, D.G., Redmond, E.M., Morrow, D., Huston, A., Shayne, M., Langstein, H.N., Miller-Graziano, C.L., Strickland, J., O'Donoghue, L., De, A.K., 2011. Heat shock protein 27 differentiates tolerogenic macrophages that may support human breast cancer progression. Cancer Res. 71, 318-327.

D’Ippolito, G., Diabira, S., Howard, G.A., Menei, P., Roos, B.A., Schiller, P.C., 2004. Marrow-isolated adult multilineage inducible (MIAMI) cells, a unique population of postnatal young and old human cells with extensive expansion and differentiation potential. J. Cell Sci. 117, 2971-2981.

D’Ippolito, G., Diabira, S., Howard, G.A., Roos, B.A., Schiller, P.C., 2006a. Low oxygen tension inhibits osteogenic differentiation and enhances stemness of human MIAMI cells. Bone 39, 513-522.

D’Ippolito, G., Howard, G.A., Roos, B.A., Schiller, P.C., 2006b. Isolation and characterization of marrow-isolated adult multilineage inducible (MIAMI) cells. Exp. Hematol. 34, 1608-1610.

D’Ippolito, G., Howard, G.A., Roos, B.A., Schiller, P.C., 2006c. Sustained stromal stem cell self-renewal and osteoblastic differentiation during aging. Rejuvenation Res. 9, 10-19.

Delcroix, G.J., Garbayo, E., Sindji, L., Thomas, O., Vanpouille-Box, C., Schiller, P.C., Montero-Menei, C.N., 2011. The therapeutic potential of human multipotent mesenchymal stromal cells combined with pharmacologically active microcarriers transplanted in hemi-parkinsonian rats. Biomaterials 32, 1560-1573.

Delcroix, G.J., Schiller, P.C., Benoit, J.P., Montero-Menei, C.N., 2010. Adult cell therapy for brain neuronal damages and the role of tissue engineering. Biomaterials 31 , 2105-2120.

Dominici, M., Le Blanc, K., Mueller, I., Slaper-Cortenbach, I., Marini, F., Krause, D., Deans, R., Keating, A., Prockop, D., Horwitz, E., 2006. Minimal criteria for defining multipotent mesenchymal stromal cells. The International Society for Cellular Therapy position statement. Cytotherapy 8, 315-317.

Garbayo, E., Raval, A.P., Curtis, K.M., Della-Morte, D., Gomez, L.A., D'Ippolito, G., Reiner, T., Perez-Stable, C., Howard, G.A., Perez-Pinzon, M.A., MonteroMenei, C.N., Schiller, P.C., 2011. Neuroprotective properties of marrow-isolated adult multilineage-inducible cells in rat hippocampus following global cerebral ischemia are enhanced when complexed to biomimetic microcarriers. J. Neurochem. 119, 972-988.

Gordon, R.J., McGregor, A.L., Connor, B., 2009. Chemokines direct neural progenitor cell migration following striatal cell loss. Mol. Cell. Neurosci. 41, 219-232.

Guillaume, D.J., Zhang, S.C., 2008. Human embryonic stem cells: a potential source of transplantable neural progenitor cells. Neurosurg. Focus 24, E3.

Ho, A.D., Wagner, W., Franke, W., 2008. Heterogeneity of mesenchymal stromal cell preparations. Cytotherapy 10, 320-330.

Horwitz, E.M., Prockop, D.J., Fitzpatrick, L.A., Koo, W.W., Gordon, P.L., Neel, M. Sussman, M., Orchard, P., Marx, J.C., Pyeritz, R.E., Brenner, M.K., 1999. Transplantability and therapeutic effects of bone marrow-derived mesenchymal cells in children with osteogenesis imperfecta. Nat. Med. 5, 309-313.

Hurst, S.M., Wilkinson, T.S., McLoughlin, R.M., Jones, S., Horiuchi, S., Yamamoto, N., Rose-John, S., Fuller, G.M., Topley, N., Jones, S.A., 2001. Il-6 and its soluble receptor orchestrate a temporal switch in the pattern of leukocyte recruitment seen during acute inflammation. Immunity 14, 705-714.

Im, G.I., Shin, Y.W., Lee, K.B., 2005. Do adipose tissue-derived mesenchymal stem cells have the same osteogenic and chondrogenic potential as bone marrowderived cells? Osteoarthritis Cartilage 13, 845-853.

Izadpanah, R., Trygg, C., Patel, B., Kriedt, C., Dufour, J., Gimble, J.M., Bunnell, B.A., 2006 Biologic properties of mesenchymal stem cells derived from bone marrow and adipose tissue. J. Cell. Biochem. 99, 1285-1297.

Jaderstad, J., Jaderstad, L.M., Li, J., Chintawar, S., Salto, C., Pandolfo, M., Ourednik, V., Teng, Y.D., Sidman, R.L., Arenas, E., Snyder, E.Y., Herlenius, E., 2010. Communication via gap junctions underlies early functional and beneficial interactions between grafted neural stem cells and the host. Proc. Natl. Acad. Sci. U.S.A. 107, 5184-5189.

Katakowski, M., Buller, B., Wang, X., Rogers, T., Chopp, M., 2010. Functional micro RNA is transferred between glioma cells. Cancer Res. 70, 8259-8263.

Kocher, A.A., Schuster, M.D., Bonaros, N., Lietz, K., Xiang, G., Martens, T.P., Kurlansky, P.A., Sondermeijer, H., Witkowski, P., Boyle, A., Homma, S., Wang, S.F., Itescu, S., 2006. Myocardial homing and neovascularization by human bone marrow angioblasts is regulated by IL-8/Gro CXC chemokines. J. Mol. Cell. Cardiol. 40 455-464.

Landry, J., Chretien, P., Lambert, H. Hickey, E., Weber, L.A., 1989. Heat shock resistance conferred by expression of the human HSP27 gene in rodent cells. J. Cell Biol. 109, 7-15.

Latchman, D.S., 2005. HSP27 and cell survival in neurones. Int. J. Hyperthermia 21 393-402.

Laudanski, K., De, A., Miller-Graziano, C., 2007. Exogenous heat shock protein 27 uniquely blocks differentiation of monocytes to dendritic cells. Eur. J. Immunol. 37, 2812-2824

Lauro, C., Cipriani, R., Catalano, M., Trettel, F., Chece, G., Brusadin, V., Antonilli, L., van Rooijen, N., Eusebi, F., Fredholm, B.B., Limatola, C., 2010. Adenosine A1 receptors and microglial cells mediate CX3CL1-induced protection of hippocampal neurons against Glu-induced death. Neuropsychopharmacology 35 , 1550-1559.

Lauro, C., Di Angelantonio, S., Cipriani, R., Sobrero, F., Antonilli, L., Brusadin, V., Ragozzino, D., Limatola, C., 2008. Activity of adenosine receptors type 1 Is required for CX3CL1-mediated neuroprotection and neuromodulation in hippocampal neurons. J. Immunol. 180, 7590-7596.

Liu, H., Jiang, D., 2011. Fractalkine/CX3CR1 and atherosclerosis. Clin. Chim. Acta 412 1180-1186.

Liu, S.P., Ding, D.C., Wang, H.J., Su, C.Y., Lin, S.Z., Li, H., Shyu, W.C., 2010. Nonsenescent Hsp27-upregulated MSCs implantation promotes neuroplasticity in stroke model. Cell Transplant. 19, 1261-1279.

Lorenz, K., Lohse, M.J., Quitterer, U., 2003. Protein kinase C switches the Raf kinase inhibitor from Raf-1 to GRK-2. Nature 426, 574-579.

Maraganore, D.M., Lesnick, T.G., Elbaz, A., Chartier-Harlin, M.C., Gasser, T., Kruger, R. Hattori, N., Mellick, G.D., Quattrone, A., Satoh, J., Toda, T., Wang, J., Ioannidis, J.P. de Andrade, M., Rocca, W.A., 2004. UCHL1 is a Parkinson's disease susceptibility gene. Ann. Neurol. 55, 512-521. 
Martin, D., Galisteo, R. Gutkind, J.S., 2009. CXCL8/IL8 stimulates vascular endothelial growth factor (VEGF) expression and the autocrine activation of VEGFR2 in endothelial cells by activating NFkappaB through the CBM (Carma3/Bcl10/Malt1) complex. J. Biol. Chem. 284, 6038-6042.

Noel, D., Caton, D., Roche, S., Bony, C., Lehmann, S., Casteilla, L., Jorgensen, C., Cousin, B., 2008. Cell specific differences between human adipose-derived and mesenchymal-stromal cells despite similar differentiation potentials. Exp. Cell Res. 314, 1575-1584.

O’Reilly, A.M., Currie, R.W., Clarke, D.B., 2010. HspB1 (Hsp 27) expression and neuroprotection in the retina. Mol. Neurobiol. 42, 124-132.

Ogihara, T., Isobe, T., Ichimura, T., Taoka, M., Funaki, M., Sakoda, H., Onishi, Y., Inukai, K., Anai, M., Fukushima, Y., Kikuchi, M., Yazaki, Y., Oka, Y., Asano, T., 1997. 14-3-3 protein binds to insulin receptor substrate-1, one of the binding sites of which is in the phosphotyrosine binding domain. J. Biol. Chem. 272, 25267-25274.

Osaka, H., Wang, Y.L., Takada, K., Takizawa, S., Setsuie, R., Li, H., Sato, Y., Nishikawa, K., Sun, Y.J., Sakurai, M., Harada, T., Hara, Y., Kimura, I., Chiba, S., Namikawa, K., Kiyama, H., Noda, M., Aoki, S., Wada, K., 2003. Ubiquitin carboxy-terminal hydrolase L1 binds to and stabilizes monoubiquitin in neuron. Hum. Mol. Genet. $12,1945-1958$

Phinney, D.G., Kopen, G., Righter, W., Webster, S., Tremain, N., Prockop, D.J., 1999. Donor variation in the growth properties and osteogenic potential of human marrow stromal cells. J. Cell. Biochem. 75, 424-436.

Provansal, M., Jorgensen, C., Lehmann, S., Roche, S., 2011. Two dimensional gel electrophoresis analysis of mesenchymal stem cells. Methods Mol. Biol. 698, 431-442.

Puissant, B., Barreau, C., Bourin, P., Clavel, C., Corre, J., Bousquet, C., Taureau, C., Cousin, B., Abbal, M., Laharrague, P., Penicaud, L., Casteilla, L., Blancher, A., 2005 Immunomodulatory effect of human adipose tissue-derived adult stem cells: comparison with bone marrow mesenchymal stem cells. Br. J. Haematol. 129, 118-129.

Rahnemai-Azar, A., D'Ippolito, G., Gomez, L.A., Reiner, T., Vazquez-Padron, R.I., PerezStable, C., Roos, B.A., Pham, S.M., Schiller, P.C., 2011a. Human marrow-isolated adult multilineage-inducible (MIAMI) cells protect against peripheral vascular ischemia in a mouse model. Cytotherapy 13 (2), 179-192.

Rahnemai-Azar, A., D'Ippolito, G., Gomez, L.A., Reiner, T., Vazquez-Padron, R.I., Perez-Stable, C., Roos, B.A., Pham, S.M., Schiller, P.C., 2011b. Human marrow-isolated adult multilineage-inducible (MIAMI) cells protect against peripheral vascular ischemia in a mouse model. Cytotherapy 13 179-192.

Rayner, K., Chen, Y.X., McNulty, M., Simard, T., Zhao, X., Wells, D.J., de Belleroche J., O'Brien, E.R., 2008. Extracellular release of the atheroprotective heat shock protein 27 is mediated by estrogen and competitively inhibits acLDL binding to scavenger receptor-A. Circ. Res. 103, 133-141.

Rayner, K., Chen, Y.X., Siebert, T., O’Brien, E.R., 2010. Heat shock protein 27: clue to understanding estrogen-mediated atheroprotection? Trends Cardiovasc. Med. 20, 54-58.

Re, D.B., Przedborski, S., 2006. Fractalkine: moving from chemotaxis to neuroprotection. Nat. Neurosci. 9, 859-861.

Reiner, T., de las Pozas, A., Gomez, L.A., Perez-Stable, C., 2009. Low dose combinations of 2-methoxyestradiol and docetaxel block prostate cancer cells in mitosis and increase apoptosis. Cancer Lett. 276, 21-31.
Roche, S., Delorme, B., Oostendorp, R.A., Barbet, R., Caton, D., Noel, D., Boumediene, K., Papadaki, H.A., Cousin, B., Crozet, C., Milhavet, O., Casteilla, L., Hatzfeld, J., Jorgensen, C., Charbord, P., Lehmann, S., 2009. Comparative proteomic analysis of human mesenchymal and embryonic stem cells: towards the definition of a mesenchymal stem cell proteomic signature. Proteomics 9, 223-232.

Roche, S., Richard, M.J., Favrot, M.C., 2007. Oct-4, Rex-1, and Gata-4 expression in human MSC increase the differentiation efficiency but not hTERT expression. J. Cell. Biochem. 101, 271-280.

Ruegg, C., Hasmim, M., Lejeune, F.J., Alghisi, G.C., 2006. Antiangiogenic peptides and proteins: from experimental tools to clinical drugs. Biochim. Biophys. Acta 1765 155-177.

Sakaguchi, Y., Sekiya, I., Yagishita, K., Muneta, T., 2005. Comparison of human stem cells derived from various mesenchymal tissues: superiority of synovium as a cell source. Arthritis Rheum. 52, 2521-2529.

Seo, J., Bakay, M., Chen, Y.W., Hilmer, S., Shneiderman, B., Hoffman, E.P., 2004. Interactively optimizing signal-to-noise ratios in expression profiling: projectspecific algorithm selection and detection $p$-value weighting in Affymetrix microarrays. Bioinformatics 20, 2534-2544.

Setsuie, R., Wada, K., 2007. The functions of UCH-L1 and its relation to neurodegenerative diseases. Neurochem. Int. 51, 105-111.

Shevchenko, A., Wilm, M., Vorm, O., Mann, M., 1996. Mass spectrometric sequencing of proteins silver-stained polyacrylamide gels. Anal. Chem. 68, 850-858.

Singh, R.K., Lokeshwar, B.L., 2009. Depletion of intrinsic expression of Interleukin8 in prostate cancer cells causes cell cycle arrest, spontaneous apoptosis and increases the efficacy of chemotherapeutic drugs. Mol. Cancer 8, 57.

Tatard, V.M., D’Ippolito, G., Diabira, S., Valeyev, A., Hackman, J., McCarthy, M., Bouckenooghe, T., Menei, P., Montero-Menei, C.N., Schiller, P.C., 2007 Neurotrophin-directed differentiation of human adult marrow stromal cells to dopaminergic-like neurons. Bone 40, 360-373.

Tessier, D.J., Komalavilas, P., Panitch, A., Joshi, L., Brophy, C.M., 2003. The small heat shock protein (HSP) 20 is dynamically associated with the actin cross-linking protein actinin. J. Surg. Res. 111, 152-157.

Tian, Q., Feetham, M.C., Tao, W.A., He, X.C., Li, L., Aebersold, R., Hood, L., 2004 Proteomic analysis identifies that 14-3-3zeta interacts with beta-catenin and facilitates its activation by Akt. Proc. Natl. Acad. Sci. U.S.A. 101, 15370-15375.

Wagner, W., Wein, F., Seckinger, A., Frankhauser, M., Wirkner, U., Krause, U., Blake, J., Schwager, C., Eckstein, V., Ansorge, W., Ho, A.D., 2005. Comparative characteristics of mesenchymal stem cells from human bone marrow, adipose tissue and umbilical cord blood. Exp. Hematol. 33, 1402-1416.

Wakitani, S., Mitsuoka, T., Nakamura, N., Toritsuka, Y., Nakamura, Y., Horibe, S., 2004 Autologous bone marrow stromal cell transplantation for repair of full-thickness articular cartilage defects in human patellae: two case reports. Cell Transplant. $13,595-600$.

Xing, Z., Gauldie, J., Cox, G., Baumann, H., Jordana, M., Lei, X.F., Achong, M.K., 1998. IL-6 is an antiinflammatory cytokine required for controlling local or systemic acute inflammatory responses. J. Clin. Invest. 101, 311-320.

Zhong, X., Rescorla, F.J. Cell surface adhesion molecules and adhesion-initiated signaling: understanding of anoikis resistance mechanisms and therapeutic opportunities. Cell Signal., in press.

Zupan, L.A., Steffens, D.L., Berry, C.A., Landt, M., Gross, R.W., 1992. Cloning and expression of a human 14-3-3 protein mediating phospholipolysis. Identification of an arachidonoyl-enzyme intermediate during catalysis. J. Biol. Chem. 267, 8707-8710. 